\title{
An FCM Approach to Better Understanding of Conflicts: A Case of New Technology Development
}

\author{
Siyamak Noori \\ Department of Industrial Engineering \\ Iran University of Science and Technology (IUST) \\ Narmak, PO box 1684613114, Tehran, Iran \\ Tel: 98-21-7391-3000Ｅ-mail: snoori@iust.ac.ir \\ Roozbeh Hesam Amiri (Corresponding author) \\ Department of Industrial Engineering \\ Iran University of Science and Technology (IUST) \\ Narmak, PO box 1684613114, Tehran, Iran
}

Tel: 98-912-5356-487 E-mail: amiri_r@ind.iust.ac.ir

\author{
Atieh Bourouni \\ Department of Industrial Engineering \\ Iran University of Science and Technology (IUST) \\ Narmak, PO box 1684613114, Tehran, Iran \\ Tel: 98-912-5007-402Ｅ-mail: bourouni@ind.iust.ac.ir
}

\begin{abstract}
A critical problem of organizational conflict management is this fact that managers fail to understand different individuals' (or groups') interpretations about goals, distribution of resources, work procedures, and etc. These various perceptions are based on stakeholders' different values, beliefs, and weltanschauung. This paper argues this main concern of organizational conflict management and develops a general systemic approach to build a platform that makes this kind of conflict easier to be analyzed. The basic idea of this platform is the cognition of individuals' thoughts and representing them in form of fuzzy cognitive maps. Once these fuzzy cognitive maps are drawn, Decision Making Trial and Evaluation Laboratory (DEMATEL) is used to analyze the maps and outrank the concepts according to their importance for a specific individual. Finally, by combining individuals' perceptions through their preference of concepts, a pluralistic environment is built. This platform is very useful for management to study the sources of conflicts among individuals and better strategies to solve them. A conflict on using Voice over IP (VoIP) technology instead of satellite telephones in offshore industry is used as an illustration of this approach.
\end{abstract}

Keywords: Organizational conflict management, Offshore industry, Decision Making Trial and Evaluation Laboratory (DEMATEL), Fuzzy cognitive map (FCM), Knowledge Integration

\section{Introduction}

In today's world, the fact that technology is all-pervasive is well known and realized. Sophisticated and rapidly changing technology is the foundation for a vast majority of products and services we depend on. Nevertheless, although technology is everywhere, its development and real-world applications are still faced with tremendous problems for technology users as well as technology developers and implementers. The introduction of new technologies leads to increases in costs due to unforeseen system performance degradation, additional downtime, and increased maintenance over a system's life cycle. In offshore industry, this behavior is amplified because of the huge amount of cost over runs that might happen. On the other hand, telecommunication technologies are one of the most important concepts in geographically separated organizations. Due to the nature of offshore industry, it needs powerful 
and reliable telecommunication systems. Along with developing a new technology in offshore telecommunication, we encountered a conflict between firms' experts in IT and planning departments. This conflict caused a huge delay in the managers' decision making process.

This paper introduces a practical approach to build a platform for better managing organizational conflicts which helps managers to understand and analyze the conflict.

The rest of the paper is set out as follows. The next section considers the previous literature on conflict and concerns its sources and management, following that is an introduction to fuzzy cognitive mapping and DEMATEL techniques. Next, a cognitive platform is built in order to better understanding of conflicts by managers. Then, the paper presents the results of the empirical study in achieving the goals as set out above with use of a case study. The final section includes conclusions.

\section{Conflict and its management}

In every organization managing means giving pride of place to people rather than to technology or structure. This characteristic for management causes conflicts to be a part of organizational life. Different individuals have different perceptions, values, beliefs, interests, goals and aims that sometimes might came into conflict. Thus, conflicts are inevitable, natural and might be harmful and damaging to organizations (Cowling et al., 1988). It is argued that these conflicts are of high importance because managers spend about 20 percent of their time dealing with them (Schermerhorn et al., 1998). Conflict by itself is neither good nor bad. However, the way in which conflicts are handled determines that it is constructive or destructive (Deutsch \& Coleman, 2000).

Although there is no universal accepted definition of conflict (Albanese, 1981), Fisher (1990) defined conflict as an incompatibility of values and goals combined with attempts to control each other and antagonistic feelings toward each other between two or more parties in a relationship. According to Thomas (1992), conflict is "the process that begins when one party perceives that the other party has negatively affected, or is about to negatively affect, something that he or she cares about".

Conflict has the potential for either a great deal of destruction or much creativity and positive social change (Kriesberg, 1998). This potential makes it necessary to understand the basic process of conflict in order to manage organizational conflicts.

The parties in an organization may have a conflict about the distribution of resources, or they may have a more fundamental conflict about the very structure of their organization and the basic nature of their interaction (Aubert, 1963).

In such circumstances management need to have an approach to tackle complicated conflicts in organization. Facing these conflicts needs a better understanding about sources, origins and causes of them.

\section{Fuzzy cognitive map}

Cognitive maps are digraphs and have their historical origins in graph theory, which started with Euler in 1736 (Biggs et al., 1976). In digraphs each relation or connection between variables or nodes has a direction (Harary et al., 1965). Axelrod (1976) was the first to use digraphs to show causal relationships among variables as defined and described by experts, rather than by the researcher himself. He called these digraphs cognitive maps. Different successful study showed cognitive mapping is effective in complex problem situations. (Bauer, 1975; Bougon et al., 1977; Brown, 1992; Carley and Palmquist, 1992; Cossette and Audet, 1992; Hart, 1977; Klein and Cooper, 1982; Malone, 1975; Montazemi and Conrath, 1986; Nakamura et al., 1982; Rappaport, 1979; Roberts, 1973).

Fuzzy Cognitive Maps (FCMs) are graphical representation including nodes determining the most relevant factors of a complex system and links between these nodes determining the relationships between those factors (Rodriguez-Repiso, 2005). FCM is a modeling methodology for complex systems, which is originated from the joining of fuzzy logic and neural networks. FCMs describe the behaviour of a complex mostly dynamic system in terms of concepts that represent an entity, a state, a variable, or a characteristic of the system (Xirogiannis \& Glykas, 2004).

FCMs have been applied in simulation (Fu, 1991), the physiology of appetite (Taber \& Siegel, 1987), modeling of organizational strategies (Paradice, 1992), political developments (Taber, 1991), support for strategic problem formulation and decision analysis (Eden \& Ackermann, 1993), electrical circuits (Styblinski \& Meyer, 1988), knowledge bases construction (Silva, 1995), virtual world of animals (Dickerson and Kosko, 1994), managerial problems diagnosis (Carrico \& Guimaraes, 1997), organizational behavior and job satisfaction (Craiger et al., 1996), failure modes effects analysis (Pelaez \& Bowles, 1995), requirements analysis (Montazemi \& Conrath, 1986), systems requirements specification (Downing \& Fickas, 1992), urban design support (Xirogiannis \& Glykas, 2004), relationship management in airline services (Kang, Sangjae, \& Choi, 2004) and web-mining inference amplification (Lee et al., 2002). 


\subsection{The FCM representation}

In Figure 1, a simple FCM (graph) representation is illustrated which has five generic vertices (C1 to C5) and the weighted arcs (edges) showing the relationships between concepts. In this simple fuzzy cognitive map, the relation between two vertices is determined by taking a value in interval $[-1,1]$. While -1 corresponds to the strongest negative, +1 corresponds to strongest positive one. The other values express different levels of influence. This model can be presented by a square matrix called adjacency matrix (Ad).

\section{Multi-step FCM conflict cognition approach}

Our multi-step FCM conflict cognition approach includes the following steps:

(1) Drawing of fuzzy cognitive maps

(2) Coding the fuzzy cognitive maps into adjacency matrices

(3) Outranking the concepts with the use of DEMATEL technique

These steps are illustrated with a real world problem situation case study on using VoIP (voice over IP) technology instead of satellite telephones in offshore industry.

\section{Illustration of FCM conflict cognition approach}

Iranian Offshore Engineering and Construction Company (IOEC) is the first Iranian general contractor to the oil and gas industry, specializing in offshore engineering, procurement, construction, pipe coating, pipe laying, and installation of jackets, TopSites, etc. IOEC designs, procures, builds, installs and services a complete range of offshore surface and partial subsurface infrastructure for the offshore oil and gas industry. With more than 400 employees operating wherever there is offshore oil and gas activity. IOEC is one of the largest truly integrated offshore and subsea pipeline companies in the Middle East.

IOEC has successfully expanded its offshore services providing projects with full marine fleet supports for pipe laying, installation, hook-up and commissioning. Today as a Holding Company, IOEC is planning to extend its oil, gas and petrochemical activities to onshore and offshore, upstream as well as downstream activities and operations. IOEC owns over $\$ 600$ million in assets including fabrication yards, concrete weight coating plant (CWC), pipe laying vessels, various lifting vessels, barges and other relevant equipment.

Over the recent years IOEC has grown considerably. This philosophy set out in this section has been developed to help IOEC maintain its position as a general contractor to the offshore oil and gas industry and to help to attain its aim of becoming "the contractor of choice across the range of products and services that they offer".

In IOEC, telecommunication project started in June 2001 with the scope of telecom building utilities, detail engineering, supply equipment/material, construction and installation, testing, commission and training. Different communication systems were developed such as VHF radio system, paging radio system, marine radio system, and satellite communication. Voice over IP (VoIP) technology is utilized as an essential for more economic communications between the company's vessels, offices in Iran and abroad.

\subsection{Step 1: Drawing of fuzzy cognitive maps}

Experts developed an FCM or a mental model manually based on their knowledge in related area. At first, they identify key domain aspects or concepts (Table 1). Secondly, each expert identifies the causal relationships among these concepts and estimates causal relationships strengths. This achieved digraph (FCM) shows not only the components and their relationships but also the strengths (Figure 2).

We collect five FCMs from each expert. All these FCMs have the same concepts (which were agreed by all five experts) but different relationships and weights. In the next step FCMs are coded into their adjacency matrices.

\subsection{Step 2: Coding the FCM graphs to matrices}

Table 2 shows one of this adjacency matrices which is based on the first FCM.

\subsection{Step 3: Determining the key concepts}

According to interviewees' matrixes, we have

$$
T=P_{1}+P_{2}+P_{3}+P_{4}+P_{5}+P_{6}+P_{7}+P_{8}
$$

Table 3 depicts the $T$ matrix. This matrix is then normalized as the DEMATEL method suggested, so we get matrix $M$ as shown in Table 4.

According to DEMATEL method, $Q$ is calculated as

$$
Q=M \times(I-M)^{-1}
$$


The $Q$ matrix is shown in Table 5 .

Table 6 shows both "direct influence" and "indirect influence" which are calculated from the $Q$ matrix.

According to the normalized total influence, we can sort concepts from most important to least important one. (Table 7)

DEMATEL method depicts the most important concepts to the least one. For example in this case Technology development (concept $\mathrm{K}$ ) is the most important concept. This importance has come from all experts' knowledge. These results can help managers for better understand the origins of organizational conflicts which might happen in their firms.

\section{Conclusion}

In today's world, it is important for managers to understand the origins of organizational conflicts in order to solve them. The proposed approach provides management with a basic model that explains the different aspects of conflicts. For sample illustration of the model, a conflict on using voice over IP (VoIP) technology instead of satellite telephones in offshore industry was used. This model was used by managers to study about the sources of conflict between IT experts.

There are indications that this model can be used in any organization which encounters conflict between its experts or decision makers. Hopefully the information provided in this paper could be a useful initial clue to the managers who are looking for ways to make leverage points to be considered for the better practices of organizational conflict management. However, it has to be admitted that the model is yet to be refined and expanded in greater detail by identifying more variables and factors and analyzing their related data in a more rational manner.

\section{References}

Albanese, R. (1981). Managing: Toward Accountability for Performance. (3rd ed.). Homewood: Richard Irwin.

Aubert, V. (1963). Competition and Dissensus. Journal of Conflict Resolution, 7, 1, $26-42$.

Axelrod, R. (1976). Structure of Decision: The Cognitive Maps of Political Elites. Princeton: Princeton University Press.

Bauer, V. (1975). Simulation, evaluation and conflict analysis in urban planning. In: Baldwin, M.M. (Ed.), Portraits of Complexity, Applications of Systems Methodologies to Societal Problems. Battelle Institute, Columbus, OH, pp. 179-192.

Biggs N.L., Lloyd E.K., \& Wilson R.J. (1976). Graph Theory: 1736-1936. Oxford: Clarendon Press.

Bougon, M., Weick, K., \& Binkhorst, D. (1977). Cognition in organizations: an analysis of the Utrecht Jazz Orchestra. Admin. Sci. Quart, 22, 606-639.

Boulding, K.E. (1957). Organizations and Conflict. Journal of Conflict Resolution, 1, 2, 122-134.

Brown, S.M. (1992). Cognitive mapping and repertory grids for qualitative survey research: some comparative observations. J. Manage. Stud. 29, 287-307.

Carley, K., \& Palmquist, M. (1992). Extracting, representing, and analyzing mental models. Social Forces, 70, 601-636

Carrico, L., \& Guimaraes, N. (1997). Facilitating analysis and diagnosis in organisations. Lectures in Computer Science, 131-144.

Cossette, P., \& Audet, M. (1992). Mapping of an idiosyncratic schema. J. Manage. Stud. 29, 325-347.

Craiger, J.P., Weiss, R.J., Goodman, D.F., \& Butler, A.A., (1996). Simulating organizational behavior with fuzzy cognitive maps. Int. J. Comput. Intel. Org. 1, 120-133.

Deutsch, M. \& Coleman, P. (eds.). (2000). The handbook of conflict resolution: Theory and practice. San Francisco: Jossey-Bass.

Dickerson J.A., \& Kosko B. (1994). Fuzzy virtual worlds, Artif. Intel. Expert, 7, 25-31.

Downing, K., \& Fickas, S. (1992). Conceptual modelling, databases, and CASE: An integrated view of information system development. New York: John Wiley.

Eden, C., \& Ackermann, F. (1993). Evaluating strategy-Its role within the context of strategic control. Journal of Operational Research Society, 44.

Fu, L. (1991) CAUSIM: A rule-based causal simulation system. Simulation, 56, 4.

Harary F, Norman R.Z., \& Cartwright D. (1965). Structural Models: An Introduction to the Theory of Directed Graphs. New York: John Wiley \& Sons.

Hart, J.A. (1977). Cognitive maps of three Latin American policy makers. World Politics, 30, 115-140. 
Kang, I., Sangjae, L., \& Choi, J. (2004). Using fuzzy cognitive map for the relationship management in airline service. Expert Systems with Applications, 26, 545-555.

Katz, D. \& Kahn, R.L. (1976). The Social Psychology of Organizations. (2nd ed.). New York: Wiley.

Klein, J.H. \& Cooper, D.F. (1982). Cognitive maps of decision-makers in a complex game. J. Operation. Res. Soc. 33, 63-71.

Lee, K. C., Kim, J. S., Chung, N. H., \& Kwon, S. J. (2002). Fuzzy cognitive map approach to webmining inference amplification. Expert Systems with Applications, 22, 197-211.

Malone, D.W. (1975). An introduction to the application of interpretive structural modeling. In: Baldwin, M.M. (Ed.), Portraits of Complexity: Applications of Systems Methodologies to Societal Problems, Battelle Institute, Columbus, OH, pp. 119-126.

Montazemi, A.R. \& Conrath, D.W. (1986). The use of cognitive mapping for information requirements analysis. MIS Quart. 10, 45-55.

Nakamura, K., Iwai, S., \& Sawaragi, T. (1982). Decision support using causation knowledge base. IEEE Trans. Syst., Man, Cybernet. SMC 12, 765-777.

Paradice, D. (1992). SIMON: An object-oriented information system for coordinating strategies and operations. IEEE Transactions on Systems, Man, and Cybernetics, 22, 3.

Pelaez, C., \& Bowles, J. (1995). Applying fuzzy cognitive maps knowledge representation to failure models effects analysis. IEEE Annual Reliability and Maintainability Symposium.

Rappaport, R.A. (1979). Ecology, Meaning, and Religion. Richmond: North Atlantic Books.

Roberts, F.S. (1973). Building and analyzing an energy demand signed digraph. Environ. Plann. 5, 199-221.

Rodriguez-Repiso, L., Setchi, R., \& Salmeron, J. (2007). Modelling IT projects success with Fuzzy Cognitive Maps. Expert Systems with Applications, 32, 543-559.

Silva, C. (1995). Fuzzy cognitive maps over possible worlds. In 4th IEEE international conference on fuzzy systems, Japan.

Styblinski M.A., \& Meyer B.D. (1988). Fuzzy cognitive maps, signal flow graphs, and qualitative circuit analysis, Proc. 2nd IEEE Internat. Conf. on Neural Networks (ICNN-87), Vol II, 549-556.

Taber R. \& Siegel M. (1987). Estimation of expert weights with fuzzy cognitive maps, Proc. 1st 1EEE lnternat. Conf. on Neural Networks (ICNN" 87), Vol. 2, 319-325.

Taber R. (1991). Knowledge processing with fuzzy cognitive maps, Expert Systems with Applications. 2, 83-87.

Thomas K.W. (1992). Conflict and negotiation processes in organisations. In Handbook of Industrial and Organisational Psychology (M.D. Dunnette \& L.M. Hough eds), pp. 651-717. Consulting Psychologists Press, Palo Alto, CA, USA.

Xirogiannis, G., \& Glykas, M. (2004). Fuzzy cognitive maps in business analysis and performance-driven change. IEEE Transactions on Engineering Management, 51, 3, 334-351. 
Table 1. Main concepts in the field of new technology development identified by each five experts

\begin{tabular}{|c|c|}
\hline Node & Concept \\
\hline A & Complexity of new technology \\
\hline B & Integration risk \\
\hline C & Technology development performance \\
\hline D & Actual testing results \\
\hline E & Discrepancy \\
\hline F & Target testing results \\
\hline G & Redevelopment \\
\hline H & Technology development risk \\
\hline I & Technology maturity \\
\hline J & Training \\
\hline K & Technology development \\
\hline L & Technology development management \\
\hline M & Testing Effort \\
\hline N & Actual Costs \\
\hline O & Cost Overrun \\
\hline P & Funding \\
\hline Q & Funding Stability \\
\hline
\end{tabular}

Table 2. The adjacency matrix for FCM $01\left(P_{1}\right)$

\begin{tabular}{|c|c|c|c|c|c|c|c|c|c|c|c|c|c|c|c|c|c|}
\hline Concepts & $\mathrm{A}$ & $\mathrm{B}$ & $\mathrm{C}$ & $\mathrm{D}$ & $\mathrm{E}$ & $\mathrm{F}$ & $\mathrm{G}$ & $\mathrm{H}$ & $\mathrm{I}$ & $\mathrm{J}$ & $\mathrm{K}$ & $\mathrm{L}$ & $\mathrm{M}$ & $\mathrm{N}$ & $\mathrm{O}$ & $\mathrm{P}$ & $\mathrm{Q}$ \\
\hline $\mathrm{A}$ & - & 0 & 0 & 0 & 0 & 0 & 0 & 0.45 & 0 & 0 & 0 & 0 & 0 & 0 & 0 & 0 & 0 \\
\hline $\mathrm{B}$ & 0 & - & 0 & 0 & 0 & 0 & 0 & 0 & 0 & 0 & 0 & 0 & 0 & 0 & 0 & 0 & 0 \\
\hline $\mathrm{C}$ & 0 & 0.6 & - & 0 & 0 & 0 & 0 & 0 & 0 & 0 & 0 & 0 & 0 & 0 & 0 & 0 & 0 \\
\hline $\mathrm{D}$ & 0 & 0 & $\begin{array}{c}0 \\
5\end{array}$ & - & 0.76 & 0 & 0 & 0 & 0 & 0 & 0 & 0 & 0 & 0 & 0 & 0 & 0 \\
& & & 4 & & & & & & & & & & & & & & \\
\hline $\mathrm{E}$ & 0 & 0 & 0 & 0 & - & 0 & 0.55 & 0 & 0 & 0 & 0 & 0 & 0 & 0 & 0 & 0 & 0 \\
\hline $\mathrm{F}$ & 0 & 0 & 0 & 0 & 0.78 & - & 0 & 0 & 0 & 0 & 0 & 0 & 0 & 0 & 0 & 0 & 0 \\
\hline $\mathrm{G}$ & 0 & 0 & 0 & 0.7 & 0 & 0 & - & 0 & 0 & 0 & 0.24 & 0 & 0 & 0 & 0 & 0 & 0 \\
\hline $\mathrm{H}$ & 0 & 0.3 & 0 & 0 & 0 & 0 & 0 & - & 0 & 0 & 0.59 & 0 & 0 & 0 & 0 & 0 & 0 \\
\hline $\mathrm{I}$ & 0 & 0 & 0 & 0 & 0 & 0 & 0 & 0.87 & - & 0 & 0 & 0 & 0 & 0 & 0 & 0 & 0 \\
\hline $\mathrm{J}$ & 0 & 0 & 0 & 0 & 0 & 0 & 0 & 0.66 & 0 & - & 0 & 0 & 0 & 0 & 0 & 0 & 0 \\
\hline $\mathrm{K}$ & 0 & 0 & 0 & 0 & 0 & 0 & 0 & 0 & 0 & 0 & - & 0.11 & 0.56 & 0 & 0 & 0 & 0 \\
\hline $\mathrm{L}$ & 0 & 0 & 0 & 0 & 0 & 0 & 0 & 0 & 0 & 0 & 0 & - & 0 & 0.11 & 0 & 0 & 0 \\
\hline $\mathrm{M}$ & 0 & 0 & 0 & 0 & 0 & 0 & 0 & 0 & 0 & 0 & 0 & 0.87 & - & 0.48 & 0 & 0 & 0 \\
\hline $\mathrm{N}$ & 0 & 0 & 0 & 0 & 0 & 0 & 0 & 0 & 0 & 0 & 0 & 0 & 0 & - & 0.34 & 0 & 0 \\
\hline $\mathrm{O}$ & 0 & 0 & 0 & 0 & 0 & 0 & 0 & 0 & 0 & 0 & 0.9 & 0 & 0 & 0 & - & 0 & 0 \\
\hline $\mathrm{P}$ & 0 & 0 & 0 & 0 & 0 & 0 & 0 & 0 & 0 & 1 & 0.68 & 0 & 0 & 0 & 0.38 & - & 0 \\
\hline $\mathrm{Q}$ & 0 & 0 & 0 & 0 & 0 & 0 & 0 & 0 & 0 & 0 & 0 & 0.45 & 0 & 0 & 0 & 0.78 & - \\
\hline
\end{tabular}


Vol. 4, No. 3

Table 3. The ( $T$ ) matrix

\begin{tabular}{|c|c|c|c|c|c|c|c|c|c|c|c|c|c|c|c|c|c|}
\hline Concept & $\mathrm{A}$ & $\mathrm{B}$ & $\mathrm{C}$ & $\mathrm{D}$ & $\mathrm{E}$ & $\mathrm{F}$ & $\mathrm{G}$ & $\mathrm{H}$ & $\mathrm{I}$ & $\mathrm{J}$ & $\mathrm{K}$ & $\mathrm{L}$ & $\mathrm{M}$ & $\mathrm{N}$ & $\mathrm{O}$ & $\mathrm{P}$ & $\mathrm{Q}$ \\
\hline $\mathrm{A}$ & - & 0 & 0 & 0 & 0 & 0 & 0.11 & 0.75 & 0.5 & 0 & 0 & 0 & 0.1 & 0 & 0.53 & 0 & 0 \\
\hline $\mathrm{B}$ & 0 & - & 0 & 0.06 & 0 & 0 & 0 & 0.34 & 0 & 0 & 0.11 & 0 & 0.65 & 0 & 0 & 0 & 0 \\
\hline $\mathrm{C}$ & 0 & 3.26 & - & 0 & 0 & 0 & 0 & 0 & 0 & 0 & 0 & 0 & 0 & 0 & 0 & 0.3 & 0 \\
\hline $\mathrm{D}$ & 0 & 0 & 1.78 & - & 0.76 & 0 & 0.1 & 0.53 & 0 & 0 & 0 & 0.2 & 0 & 0 & 0 & 0 & 0 \\
\hline $\mathrm{E}$ & 0 & 0 & 0 & 0.67 & - & 0 & 3.05 & 0 & 0 & 0.12 & 0.5 & 0 & 0 & 1 & 0.3 & 0 & 0 \\
\hline $\mathrm{F}$ & 0 & 0 & 0 & 0 & 2.79 & - & 0 & 0 & 1.2 & 0 & 0 & 0 & 0.69 & 0 & 0 & 0 & 0 \\
\hline $\mathrm{G}$ & 0 & 0 & 0 & 1.81 & 0 & 0 & - & 0 & 0 & 0 & 0.79 & 0 & 0 & 0 & 0 & 0 & 0 \\
\hline $\mathrm{H}$ & 0 & 1.1 & 0 & 0 & 0 & 0.9 & 0 & - & 0 & 0 & 2.5 & 0 & 0 & 0.24 & 0 & 0 & 0.11 \\
\hline $\mathrm{I}$ & 0 & 0 & 0 & 0 & 0.5 & 0 & 0 & 2.28 & - & 0 & 0 & 0 & 0 & 0.84 & 0 & 0 & 0.46 \\
\hline $\mathrm{J}$ & 0 & 0 & 0 & 0.93 & 0 & 0 & 0 & 2.52 & 0 & - & 0 & 0 & 0 & 0 & 0 & 0 & 0 \\
\hline $\mathrm{K}$ & 0 & 1.28 & 0 & 0 & 0 & 0.54 & 0 & 0.52 & 0 & 0 & - & 2.29 & 2.58 & 0 & 0 & 0 & 0 \\
\hline $\mathrm{L}$ & 0 & 0 & 1.59 & 0 & 0 & 0 & 0 & 0 & 0 & 0 & 0 & - & 0.45 & 1.28 & 0 & 0 & 0 \\
\hline $\mathrm{M}$ & 0 & 0 & 0 & 0 & 0 & 0 & 0 & 0 & 0 & 0 & 0 & 2.88 & - & 1.82 & 0 & 0.25 & 0 \\
\hline $\mathrm{N}$ & 0 & 0 & 0 & 0 & 0.21 & 0 & 0 & 0 & 0 & 0 & 0 & 0 & 0 & - & 1.08 & 0 & 0 \\
\hline $\mathrm{O}$ & 0 & 0 & 0 & 0 & 0 & 0 & 0 & 0 & 0.05 & 0 & 2.54 & 0 & 0 & 0 & - & 0 & 0 \\
\hline $\mathrm{P}$ & 0 & 0.25 & 0.38 & 0 & 0.65 & 0 & 0 & 0 & 0 & 2.73 & 2.16 & 0 & 0 & 0 & 1.17 & - & 0 \\
\hline $\mathrm{Q}$ & 0 & 0 & 0 & 0 & 0 & 0 & 0 & 1.12 & 0 & 0 & 0 & 1.4 & 0 & 0 & 0 & 1.71 & - \\
\hline
\end{tabular}

Table 4. The ( $M)$ matrix

\begin{tabular}{|c|c|c|c|c|c|c|c|c|c|c|c|c|c|c|c|c|c|}
\hline Concept & $\mathrm{A}$ & B & $\mathrm{C}$ & $\mathrm{D}$ & $E$ & $\mathrm{~F}$ & $\mathrm{G}$ & $\mathrm{H}$ & I & $\mathrm{J}$ & $\mathrm{K}$ & $\mathrm{L}$ & $\mathrm{M}$ & $\mathrm{N}$ & $\mathrm{O}$ & $P$ & $\mathrm{Q}$ \\
\hline A & 0 & 0 & 0 & 0 & 0 & 0 & 0.01 & 0.1 & 0.07 & 0 & 0 & 0 & 0.013624 & 0 & 0.072207 & 0 & 0 \\
\hline B & 0 & 0 & 0 & 0.01 & 0 & 0 & 0 & 0.05 & 0 & 0 & 0.014986 & 0 & 0.088556 & 0 & 0 & 0 & 0 \\
\hline $\mathrm{D}$ & 0 & 0 & 0.2 & 0 & 0.1 & 0 & 0.01 & 0.07 & 0 & 0 & 0 & 0.027248 & 0 & 0 & 0 & 0 & 0 \\
\hline $\mathrm{E}$ & 0 & 0 & 0 & 0.09 & 0 & 0 & 0.42 & 0 & 0 & 0.02 & 0.06812 & 0 & 0 & 0.13624 & 0.040872 & 0 & 0 \\
\hline $\mathrm{H}$ & 0 & 0.15 & 0 & 0 & 0 & 0.12 & 0 & 0 & 0 & 0 & 0.340599 & 0 & 0 & 0.032698 & 0 & 0 & 0.014986 \\
\hline I & 0 & 0 & 0 & 0 & 0.07 & 0 & 0 & 0.31 & 0 & 0 & 0 & 0 & 0 & 0.114441 & 0 & 0 & 0.06267 \\
\hline $\mathrm{J}$ & 0 & 0 & 0 & 0.13 & 0 & 0 & 0 & 0.34 & 0 & 0 & 0 & 0 & 0 & 0 & 0 & 0 & 0 \\
\hline $\mathrm{K}$ & 0 & 0.17 & 0 & 0 & 0 & 0.07 & 0 & 0.07 & 0 & 0 & 0 & 0.311989 & 0.351499 & 0 & 0 & 0 & 0 \\
\hline $\mathrm{O}$ & 0 & 0 & 0 & 0 & 0 & 0 & 0 & 0 & 0.01 & 0 & 0.346049 & 0 & 0 & 0 & 0 & 0 & 0 \\
\hline$P$ & 0 & 0.03 & 0.1 & 0 & 0.09 & 0 & 0 & 0 & 0 & 0.37 & 0.294278 & 0 & 0 & 0 & 0.159401 & 0 & 0 \\
\hline $\mathrm{Q}$ & 0 & 0 & 0 & 0 & 0 & 0 & 0 & 0.15 & 0 & 0 & 0 & 0.190736 & 0 & 0 & 0 & 0.23297 & 0 \\
\hline
\end{tabular}


Table 5. The ( $Q)$ matrix

\begin{tabular}{|c|c|c|c|c|c|c|c|c|c|c|c|c|c|c|c|c|c|}
\hline Concepts & A & B & C & D & E & F & G & $\mathrm{H}$ & I & $\mathrm{J}$ & K & L & M & $\mathrm{N}$ & 0 & $P$ & Q \\
\hline $\mathrm{A}$ & 0 & 0389905 & 011709 & 0072314 & 0154192 & 0221626 & 0214921 & 1340301 & 0722783 & & 0778638 & 0450779 & 0492929 & 0.0348383 & 0.0785501 & 0.0036807 & 0.0065383 \\
\hline B & 0 & 0 & 0143686 & 0097786 & 0060829 & 0090998 & 0026608 & 0518454 & .0015332 & .0017577 & 0.0372808 & 0.0543177 & 1076879 & 0.0388736 & 0.0066791 & 0.0044585 & 0.0008731 \\
\hline $\mathrm{C}$ & 0 & 4611227 & 0 & 0073384 & 0076699 & .006255 & 0032871 & .030329 & .0010935 & .0162455 & 0.0344736 & 0.0328532 & .0555547 & 0.0216661 & 0.01041 & 0.0433413 & 0.0005231 \\
\hline D & 0 & 397139 & 2627231 & 0 & 1143555 & .014748 & 0615178 & 0877277 & 0.0024946 & 0.006453 & 0.0542513 & 0.059518 & 0.0364771 & 0.0381576 & 0.0122527 & 0.0123231 & 0,0014711 \\
\hline$E$ & 0 & 0624432 & 0670392 & 2036658 & 0 & 0158527 & 4319031 & 0.0361188 & 0.003058 & 0.018809 & 0.1552818 & 0.0802361 & .0665204 & 0.1727151 & 0.0684476 & 0.0051765 & 0.0007329 \\
\hline F & 0 & 430423 & 384241 & 8813141 & 0.409932 & 0 & 1714474 & 0707909 & 1661953 & 0.0099876 & 0.086398 & 0.0842372 & 0.1347638 & 0.1252888 & 0.0365977 & 0.0088342 & 0.0114764 \\
\hline G & 0 & & & & 0329269 & 0132803 & 0 & & .0022176 & .0024657 & & 0.0686363 & .0556599 & 0.0315527 & & & 0.0006168 \\
\hline $\mathrm{H}$ & 0 & 2452744 & 0465756 & 0159048 & 0677815 & 70618 & 0.028382 & 0 & 0.0258358 & 0.0056338 & 0.3813164 & 0.1942961 & 0.1824292 & 0.1257107 & 0.0232069 & 0.0121678 & 0.0173869 \\
\hline I & 0 & & & & & & & & 0 & .0087744 & & & .0694144 & 0.1722326 & & & 683616 \\
\hline $\mathrm{J}$ & 0 & 1019108 & 0492783 & 1356564 & .0377602 & 0557918 & 0175387 & 3723394 & 0091861 & 0 & 0.137789 & 0.0742477 & .0672541 & 0.0479942 & \begin{tabular}{|l|l|}
0.0095199 \\
\end{tabular} & 0.0057389 & 0.0061557 \\
\hline $\mathrm{K}$ & 0 & & & & .0439244 & & & & 0.0148885 & & 0 & 0.5013455 & 0.4335701 & 0.2057359 & & & 0.00236 \\
\hline $\mathrm{L}$ & 0 & 1055895 & 2261721 & 0030366 & .0081557 & .0024889 & 0.0034303 & 0.0083234 & 0.000625 & 0.004602 & 0.019958 & 0 & 0.0802262 & 0,2023295 & 0.0320191 & 0.0120148 & 0.0001639 \\
\hline $\mathrm{M}$ & 0 & 0.0514971 & 0.0946101 & 0.0052843 & 0.0152454 & 0.0040779 & & & & & & & 0 & & & & 0.000229 \\
\hline $\mathrm{N}$ & 0 & 0.0145843 & 0.0076685 & 0.0064394 & 0.0318809 & 0.0050686 & 0.0133352 & 0.006225 & 0.0018567 & 0.0009606 & 0.0585206 & 0.0279093 & 0.024049 & 0 & 0.1509241 & 0.0011814 & 0.0002097 \\
\hline 0 & 0 & & & & & & & & & & & & 0.1505094 & 0.072368 & 0 & 0.0070225 & 0.0012823 \\
\hline $\mathrm{P}$ & 0 & 0.1893918 & 0.1164238 & 0.0732868 & 0.121557 & 0.0541553 & 0.0515092 & 0.178664 & 0.0100943 & 0.3783732 & 0.4383375 & 0.2135547 & 0.1890303 & 0.1076704 & 0.182119 & 0 & 0.0033101 \\
\hline Q & 0 & 0.1016884 & 0.0773692 & 0.0200797 & 0.0402174 & 0.0370571 & 0.0169852 & 0.2037549 & 0.0064131 & 0.089887 & 0.1641107 & 0.2773483 & 0.087177 & 0.0828574 & 0.0520766 & 0.2399065 & 0 \\
\hline
\end{tabular}

Table 6. DEMATEL direct and indirect influences

\begin{tabular}{|c|c|c|c|c|}
\hline Concept & $\begin{array}{c}\text { Direct Influence } \\
\text { Index }\end{array}$ & $\begin{array}{c}\text { Indirect Influence } \\
\text { Index }\end{array}$ & Total Influence & $\begin{array}{c}\text { Normalized Total } \\
\text { Influence }\end{array}$ \\
\hline $\mathrm{A}$ & 0.620776 & 0 & 0.620776 & 0.016356 \\
\hline $\mathrm{B}$ & 0.347298 & 2.0416294 & 2.388927 & 0.062941 \\
\hline $\mathrm{C}$ & 0.732163 & 1.2655442 & 1.997707 & 0.052634 \\
\hline $\mathrm{D}$ & 0.904185 & 0.8602501 & 1.764435 & 0.046488 \\
\hline $\mathrm{E}$ & 1.388 & 1.0663462 & 2.454346 & 0.064665 \\
\hline $\mathrm{F}$ & 1.47873 & 0.5708345 & 2.049564 & 0.054 \\
\hline $\mathrm{G}$ & 0.771461 & 0.8957831 & 1.667245 & 0.043927 \\
\hline $\mathrm{H}$ & 1.528964 & 1.6961855 & 3.225149 & 0.084973 \\
\hline $\mathrm{I}$ & 1.270883 & 0.3308439 & 1.601727 & 0.042201 \\
\hline $\mathrm{J}$ & 1.128161 & 0.5714978 & 1.699659 & 0.044781 \\
\hline $\mathrm{K}$ & 1.841999 & 2.323768 & 4.165767 & 0.109755 \\
\hline $\mathrm{L}$ & 0.709135 & 2.395455 & 3.10459 & 0.081797 \\
\hline $\mathrm{M}$ & 1.093442 & 1.7896163 & 2.883058 & 0.07596 \\
\hline $\mathrm{N}$ & 0.350813 & 1.8148682 & 2.165681 & 0.057059 \\
\hline $\mathrm{O}$ & 1.00707 & 0.7934544 & 1.800525 & 0.047438 \\
\hline $\mathrm{P}$ & 2.307477 & 0.4397186 & 2.747196 & 0.07238 \\
\hline $\mathrm{Q}$ & 1.496929 & 0.1216908 & 1.618619 & 0.042646 \\
\hline
\end{tabular}


Table 7. Total influence matrix

\begin{tabular}{|c|c|c|}
\hline \multicolumn{2}{|r|}{ Concept } & \multirow{2}{*}{$\begin{array}{c}\text { Normalized Total Influence } \\
0.109755\end{array}$} \\
\hline $\mathrm{K}$ & Technology development & \\
\hline $\mathrm{H}$ & Technology development risk & 0.084973 \\
\hline $\mathrm{L}$ & Technology development management & 0.081797 \\
\hline M & Testing Effort & 0.07596 \\
\hline $\mathrm{P}$ & Funding & 0.07238 \\
\hline $\mathrm{E}$ & Discrepancy & 0.064665 \\
\hline $\mathrm{B}$ & Integration risk & 0.062941 \\
\hline $\mathrm{N}$ & Actual Costs & 0.057059 \\
\hline $\mathrm{F}$ & Target testing results & 0.054 \\
\hline $\mathrm{C}$ & Technology development performance & 0.052634 \\
\hline $\mathrm{O}$ & Cost Overrun & 0.047438 \\
\hline $\mathrm{D}$ & Actual testing results & 0.046488 \\
\hline $\mathrm{J}$ & Training & 0.044781 \\
\hline G & Redevelopment & 0.043927 \\
\hline Q & Funding Stability & 0.042646 \\
\hline I & Technology maturity & 0.042201 \\
\hline $\mathrm{A}$ & Complexity of new technology & 0.016356 \\
\hline
\end{tabular}

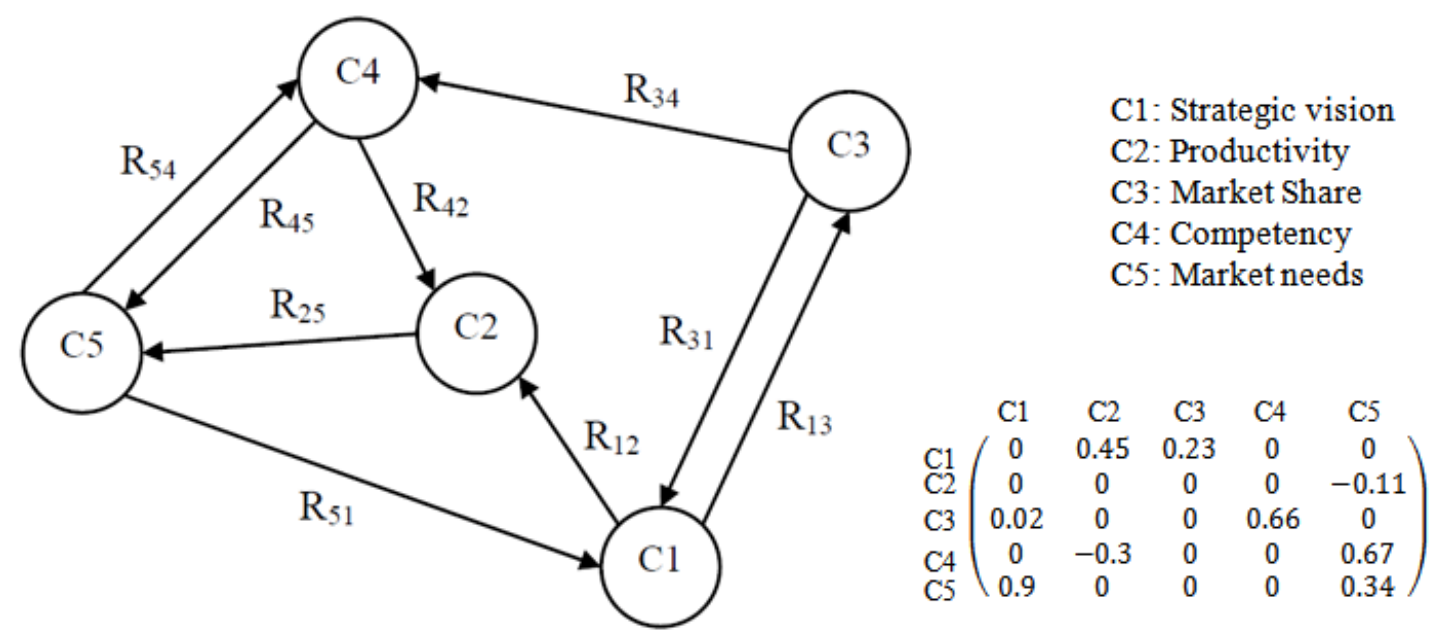

Figure 1. Representing a simple fuzzy cognitive map 


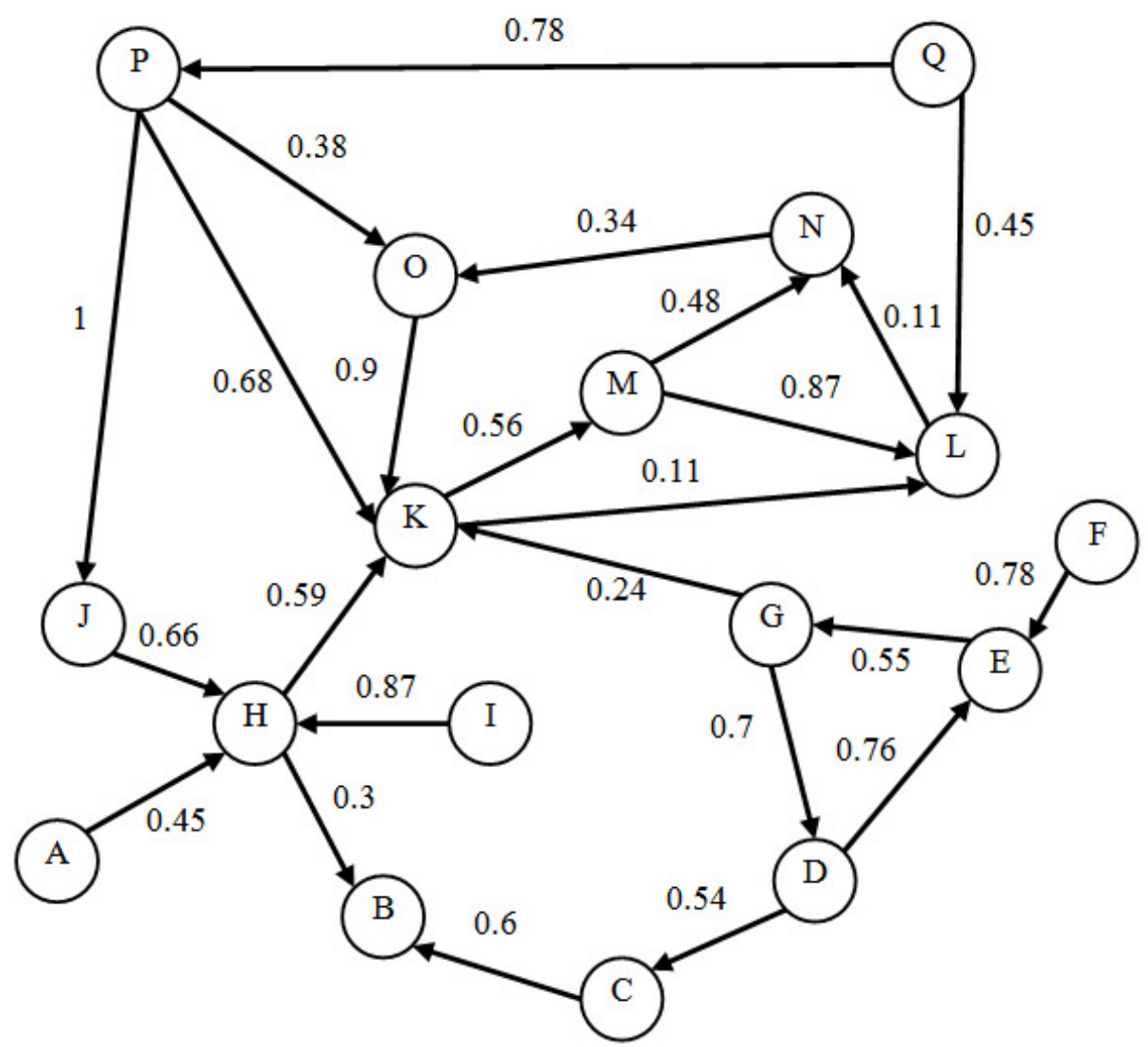

Figure 2. A fuzzy cognitive map describing the development of new technology which is drawn by one expert (FCM 01) 